\title{
KEDUDUKAN JAMINAN HAK TANGGUNGAN YANG DIBUAT TANPA PERSETUJUAN MANTAN ISTRI DALAM PERBANKAN : STUDI PUTUSAN MAHKAMAH AGUNG NOMOR 222K/PDT /2017
}

\author{
Rahmadi Indra Tektona1, Dwi Budi Wasitaresi² \\ 1,2Fakultas Hukum Universitas Jember, Jl. Kalimantan No.37, Krajan Timur, Sumbersari, Kec. \\ Sumbersari, Kabupaten Jember, Jawa Timur \\ Email : rahmadiindra@unej.ac.id
}

\begin{abstract}
The bank in providing financing or credit to the public has confidence in the ability of the debtor to repay the debt according to the contents of the agreed agreement. One of them is the provision of collateral as collateral by the debtor to the bank as the creditor. The authority related to the granting of Mortgage Rights is stated in article 8 paragraph (1) of the Mortgage Rights Law. If the object of guarantee is in a marriage, then the object of guarantee is said to be joint property so that the object of guarantee belongs to the husband and wife. However, a marriage that is broken up due to divorce will result in the authority related to the joint property. This study aims to determine the rules regarding collateral derived from assets obtained during marriage belonging to a divorced / separated husband and wife. The research method used is the juridical normative research method and the qualitative approach so that it focuses on research related to the application of the rules and norms in positive law which results in legal certainty in the provision of collateral that comes from joint assets obtained during the marriage of a married couple which has ended due to unregulated divorce. in Banking Law.
\end{abstract}

Keywords : Banking Law, Mortgage Guarantee, Marriage Law

\begin{abstract}
ABSTRAK
Bank dalam memberikan pembiayaan atau kredit kepada masyarakat memiliki keyakinan atas kesanggupan debitur dalam rangka pengembalian hutang sesuai isi perjanjian yang telah disepakati. Salah satunya yakni diberikannya jaminan hak tanggungan sebagai agunan oleh debitur kepada pihak bank selaku kreditur. Kewenangan terkait pemberian Hak Tanggungan tercantum pada pasal 8 ayat (1) Undang - Undang Hak Tanggungan. Apabila objek jaminan terdapat dalam sebuah perkawinan, maka objek jaminan tersebut dikatakan sebagai harta bersama sehingga objek jaminan itu milik pasangan suami istri tersebut. Namun, perkawinan yang putus karena perceraian akan berakibat pada kewenangan terkait harta bersama tersebut. Penelitian ini bertujuan untuk mengetahui aturan mengenai benda jaminan yang berasal dari harta yang diperoleh semasa perkawinan milik sepasang suami istri yang sudah bercerai/berpisah. Metode penelitian yang digunakan yaitu metode penelitian Yuridis Normatif serta pendekatan kualitative sehingga memfokuskan penelitian terkait penerapan kaidah serta norma dalam hukum positif yang menghasilkan Kepastian hukum dalam pemberian benda jaminan yang berasal dari harta Bersama yang didapat semasa perkawinan pasangan suami istri yang sudah berakhir disebabkan perceraian tidak diatur dalam Hukum Perbankan.
\end{abstract}

Kata Kunci: Hukum Perbankan, Jaminan Hak Tanggungan, Hukum Perkawinan

\section{PENDAHULUAN}

Pernikahan merupakan suatu lembaga yang sakral dan memiliki payung hukum yang jelas di Indonesia (Budiawan, 2018), kedudukan suami istri dalam perkawinan yang sah telah dijamin oleh

* Copyright (c) 2020 Rahmadi Indra Tektona et.all

This work is licensed under a Creative Commons Attribution-ShareAlike 4.0 International License.

Diterima: 8 Mei 2020; Direvisi: 16 Agustus 2020; Disetujui: 18 Agustus 2020 
Khazanah Hukum, Vol. 2 No. 2: 82-91

Kedudukan Jaminan Hak Tanggungan Yang Dibuat Tanpa Persetujuan Mantan Istri Dalam Perbankan : Studi Putusan Mahkamah Agung Nomor 222k/Pdt/2017

Rahmadi Indra Tektona dan Dwi Budi Wasitaresi

Negara dan memiliki kepastian hukum bagi masing - masing pihak, seperti pendapat Sudikno Mertokusumo. Pada pengertiannya, kepastian hukum itu sendiri merupakan jaminan bahwasannya hukum itu dilaksanakan, lalu mereka yang memiliki hak menurut ketentuan hukum mendapatkan haknya serta dilaksanakannya putusan tersebut (Mertokusumo, 2010). Kepastian hukum mendorong dibuatnya aturan hukum dalam bentuk perundang - undangan oleh pihak yang diberi kewenangan atas itu, sehingga aturan tersebut mempunyai aspek yuridis dan dapat memberikan jaminan mengenai adanya suatu kepastian bahwasannya hukum telah mejalankan fungsinya sebagai peraturan yang wajib untuk ditaati. Bank berperan mengumpulkan dana yang berasal dari masyarakat berbentuk simpanan yang kemudian didistribusikan kembali pada masyarakat berupa kredit yang dapat digunakan untuk meningkatkan kegiatan usahanya guna meningkatkan kesejahteraan hidup masyarakat. Ketika bank memberikan pembiayaan atau dapat disebut dengan kredit, diwajibkan memiliki keyakinan terhadap kemampuan pihak debitur untuk pengembalian hutang itu sesuai dengan isi perjanjian yang telah disepakati (Pius, 2013). Pada dasarnya, pengertian mengenai kredit terdapat pada pasal 1 Angka 11 Undang - Undang Nomor 10 Tahun 1998 tentang Perubahan atas Undang - Undang Nomor 7 Tahun 1992 tentang Perbankan (selanjutnya disebut Undang - Undang Perbankan) bahwa :

"Kredit adalah penyediaan uang atau tagihan yang dapat dipersamakan dengan itu, berdasarkan persetujuan atau kesepakatan pinjam - meminjam antara bank dengan pihak lain yang mewajibkan pihak peminjam untuk melunasi utangnya setelah jangka waktu tertentu dengan pemberian bunga."

Persetujuan antara Bank bersama debitur yang diwujudkan pada sebuah Perjanjian Kredit menimbulkan adanya perikatan sesuai Pasal 1234 Kitab Undang - Undang Hukum Perdata (KUHPerdata) antara lain memberikan sesuatu, berbuat sesuatu, atau tidak berbuat sesuatu sehingga Kreditur dan Debitur memiliki prestasi masing - masing yang wajib untuk dipenuhi (Suyandi, 2019).

Pada praktek perbankan, Bank selalu berpegang pada asas "Commanditerings verbood" yang artinya Bank tidak mau menanggung risiko usaha debitur dengan kredit yang diberikan sehingga bank dalam menjalankan salah satu kegiatan usahanya yaitu memberikan kredit selalu berpegang pada prinsip kehati - hatian (Pius, 2013). Adapun yang disebut sebagai prinsip kehati - hatian pada praktik perbankan untuk menganalisa debitor adalah prinsip 5C meliputi Character, Capacity, Capital, Collateral, dan Condition of Economic. Pelaksanaan prinsip kehati - hatian tersebut diwujudkan ke dalam bentuk sebuah perjanjian tertulis yang disebut sebagai Perjanjian Kredit.

Mariam Darus Badrulzaman memberikan pendapatnya terkait pengertian mengenai perjanjian kredit bank, bahwa perjanjian kredit yaitu perjanjian pendahuluan sebelum diserahkannya uang kepada debitur (Zaman \& Darus, 1991). Kesepakatan antara bank dengan debitur pada perjanjian pendahuluan tersebut melahirkan ikatan hukum bagi kedua belah pihak (Zaman \& Darus, 1991). Sehingga yang dimaksud dengan perjanjian kredit merupakan perjanjian yang memiliki hubungan timbal balik (Obligatoir) baik diantara para pihak yang terikat dengan prestasi masing - masing.

Saat dihubungkan dengan jenis - jenis perjanjian maka Perjanjian Kredit dikategorikan dalam perjanjian tidak bernama (Munif, 2017). Hal itu disebabkan karena perjanjian tersebut belum diatur secara khusus dalam KUHPerdata. Perjanjian ini lahir karena adanya asas kebebasan berkontrak sehingga didasarkan atas kesepakatan antara kedua pihak diperkenankan membuat sendiri ketentuan yang dikehendakinya sesuai tujuan hubungan bisnis mereka. Meskipun ketentuan yang dimaksud dirumuskan oleh para pihak sebagai masyarakat biasa karena diwujudkan dengan perjanjian, tetapi perjanjian tersebut tetap disebut sah jika ketentuan pasal 1320 KUHPerdata mengenai syarat sahnya perjanjian telah 
Khazanah Hukum, Vol. 2 No. 2: 82-91

Kedudukan Jaminan Hak Tanggungan Yang Dibuat Tanpa Persetujuan Mantan Istri Dalam Perbankan : Studi Putusan Mahkamah Agung Nomor 222k/Pdt/2017

Rahmadi Indra Tektona dan Dwi Budi Wasitaresi

terpenuhi serta berkekuatan seperti undang - undang terhadap para pihaknya sebagaimana bunyi Pasal 1338 KUHPerdata.

Penelitian yang lebih dahulu membahas tentang Kedudukan Jaminan Hak Tanggungan Yang Dibuat Tanpa Persetujuan Mantan Istri Dalam Perbankan pernah diteliti oleh Taka (2015) yang meneliti tentang harta Bersama yang diperjualkan tanpa seizin suami./istri menghasilkan bahwa Harta tersebut tidak sah dan batal demi hukum, Purwandari (2018) meneliti tentang Kedudukan Dan Perlindungan Hukum Terhadap Kreditur Apabila Hak Tanggungan Dinyatakan Batal Demi Hukum Di Pengadilan menghasilkan bahwa kreditur pemegang hak tanggungan tetap dapat meminta haknya (penyelesaian piutangnya) kepada debitur, meskipun tanpa adanya jaminan dan penelitian yang dilakukan oleh Ibrahim, Turatmiyah, \& Handayani (2019) yang mengkaji hak tanggung pada Putusan Mahkamah Agung Nomor: $2301 \mathrm{~K} / \mathrm{Pdt} / 2007$ menyatakan bahwa upaya hukum yang dapat dilakukan oleh kreditur adalah dengan mengajukan gugatan perdata terhadap harta kekayaan lainnya untuk mengambil pelunasan dari piutang kreditur. Pada penelitian ini mempunyai perbedaan dari penelitian yang telah dilakukan penelitian ini berfokus pada Kedudukan Jaminan Hak Tanggungan Yang Dibuat Tanpa Persetujuan Mantan Istri Dalam Perbankan : Studi Putusan Mahkamah Agung Nomor 222k/Pdt/2017 yang mempunyai studi kasus dan objek yang berbeda dari penelitian sebelumnya.

Pada praktiknya, kedudukan Kreditur yang hanya bergantung pada perjanjian pokoknya saja dirasa kurang kuat dalam menjamin posisi Kreditur dalam memberikan kredit terhadap Debitur. Di sisi lain tindakan penyaluran kredit atau pinjaman bank tersebut membuka peluang terjadinya kemacetan kredit (Khoidin, 2017). Sehingga apabila Debitur wanprestasi, Kreditur akan kesulitan untuk meminta kembali atas bentuk pelunasan kredit tersebut. Demi menjamin kedudukan yang aman bagi Kreditur sebagai pemberi kredit kepada Debitur, maka Kreditur dapat membuat perjanjian accesoir terhadap perjanjian pokok tersebut.

Perjanjian accesoir lahir sebagai akibat dari perjanjian pokok yang mendahuluinya (Nurfaizal, 2013). Perjanjian tambahan ini dapat berbentuk perjanjian jaminan kebendaan dari Debitur sebagai bentuk pengikatan pelunasan apabila Debitur wanprestasi. Terkait hal ini, pada dasarnya perjanjian kredit yaitu perjanjian pokok yang melandasi perjanjian jaminan (Isnaeni, 2016). Adapun pengertian mengenai jaminan kebendaan adalah benda yang memiliki keterikatan secara langsung terhadap debitur yang kemudian dijadikan sebagai jaminan. Kreditur sebagai pemegang jaminan ini mempunyai hak kebendaan (zakenlijk recht). Adapun karakteristik hak kebendaan yang dimiliki oleh pemegang jaminan ini yaitu dapat dipertahankan dari siapapun (droit de suite, zaakgevolg) dan senantiasa mengikuti bendanya (Khoidin, 2017).

Hak Tanggungan sebagai salah satu lembaga jaminan kebendaan yang pada pengertiannya bahwa :

"Hak Tanggungan adalah hak jaminan yang dibebankan pada hak atas tanah sebagaimana dimaksud dalam Undang - Undang Nomor 5 Tahun 1960 tentang Peraturan Dasar Pokok - Pokok Agraria, berikut atau tidak berikut benda - benda lain yang merupakan satu kesatuan dengan tanah itu, untuk pelunasan utang tertentu, yang memberikan kedudukan yang diutamakan kepada kreditur tertentu terhadap kreditur - kreditur lain."

Jaminan Hak Tanggungan pada prakteknya di buat oleh Pejabat Pembuat Akta Tanah dalam bentuk Akta Pemberian Hak Tanggungan (selanjutnya disebut dengan APHT) yang di dalamnya berisikan mengenai kebendaan, baik berupa tanah beserta dengan bangunan diatasnya yang dijadikan jaminan terhadap pelunasan atas utang peminjam atau Debitur kepada pemberi pinjaman atau Kreditur. 
Khazanah Hukum, Vol. 2 No. 2: 82-91

Kedudukan Jaminan Hak Tanggungan Yang Dibuat Tanpa Persetujuan Mantan Istri Dalam Perbankan : Studi Putusan Mahkamah Agung Nomor 222k/Pdt/2017

Rahmadi Indra Tektona dan Dwi Budi Wasitaresi

Sehubungan dengan hal diatas, penulis mengkaji Putusan Mahkamah Agung Nomor 222 K/Pdt/2017 tentang sengketa Jaminan berupa Hak Tanggungan gambaran kasus secara garis besar sebagai berikut:

Permasalahan berawal dari Hj. Idatul Ifa selaku Penggugat telah menikah dengan Zainul Arifin selaku Tergugat I pada tahun 1993. Selama pernikahan tersebut keduanya telah memperoleh sebidang tanah pekarangan yang diatas tanah tersebut didirikan bangunan permanen atas nama Zainul Arifin. Kemudian, keduanya memutuskan untuk bercerai di tahun 2006. Namun, sampai gugatan ini diajukan belum dilakukan pembagian harta bersama. Lalu pada tanggal 20 April 2007 tanpa sepengetahuan dan tanpa persetujuan Hj. Idatul Ifa, Zainul Arifin meminjam sejumlah dana kepada Bank Danamon selaku Tergugat II dan menggunakan tanah dan bangunan tersebut dijadikan jaminan atas perjanjian kredit. Bank Danamon juga menyepakati dan meniadakan dan tidak melakukan survey, klarifikasi, dan verifikasi hak Kepemilikan atas tanah dan bangunan sebagai agunan atau jaminan tersebut kepada Hj. Idatul Ifa, sehingga menurut $\mathrm{Hj}$. Idatul Ifa patut dinyatakan melanggar prinsip kehati - hatian. Bahwa faktanya nilai kredit yang disepakati bank Danamon dengan Zainul Arifin nyata - nyata melebihin plafon kredit yang ditetapkan oleh Bank Indonesia, yang berakibat macetnya kredit Tergugat I dalam tenggang waktu yang sangat singkat, bahkan untuk mengaburkan tindakan perbuatan melawan hukumnya, Bank Danamon juga memohon dan mengajukan dilaksanakannya lelang terhadap Kantor Pelayanan Kekayaan Negara dan Lelang Surabaya atas tanah dan bangunan a quo, yang akhirnya ditetapkan sebagai pemenang lelang adalah H. Soelikin selaku Tergugat IV.

Berdasarkan uraian diatas, dapat ditarik suatu permasalahan yaitu Kedudukan Jaminan Hak Tanggungan Yang Dibuat Tanpa Persetujuan Mantan Istri Dalam Hukum Perbankan (Studi Putusan Mahkamah Agung Nomor 222 K/Pdt/2017).

\section{METODOLOGI PENELITIAN}

Menggunakan pendekatan kualitatif (Sugiyono, 2013) Pada penulisan karya ilmiah ini, tipe penelitian yang digunakan ialah yuridis normatif atau penelitian hukum doktrinal, serta menggunakan pendekatan peraturan perundang- undangan, pendekatan konseptual dan pendekatan kasus untuk mengkaji permasalahan yang ada. Kemudian bahan hukum sekunder adalah pendapat, penjelasan, kesimpulan dari para ahli hukum dengan pengumpulan data yang diperoleh dari studi kepustakaan, jurnal, buku, bahan kuliah umum, internet. Langkah selanjutnya yang dipergunakan dalam suatu penelitian hukum adalah melakukan telaah atas isu hukum yang telah dirumuskan dalam rumusan masalah untuk menarik kesimpulan berdasarkan bahan-bahan hukum yang sudah terkumpul dengan menggunakan metode analisa bahan hukum deduktif yaitu berpangkal dari suatu permasalahan yang secara umum sampai dengan hal-hal yang bersifat khusus. Sehingga pada akhirnya penulis dapat memberikan preskripsi mengenai apa yang seharusnya dilakukan dan dapat diterapkan untuk mejadikan solusi dalam permasalahan ..

\section{HASIL DAN PEMBAHASAN}

\section{Pengaturan Benda Jaminan Berasal Dari Harta Bersama Pasangan Suami Istri Yang Sudah Bercerai}

Pada tanggal 18 September $2013 \mathrm{Hj}$. Idatul Ifa sebagai Penggugat mengajukan gugatan terhadap Zainul Arifin Tergugat I, Direktur Utama PT. Bank Danamon Indonesia Tbk sebagai Tergugat II, Kepala 
Khazanah Hukum, Vol. 2 No. 2: 82-91

Kedudukan Jaminan Hak Tanggungan Yang Dibuat Tanpa Persetujuan Mantan Istri Dalam Perbankan : Studi Putusan Mahkamah Agung Nomor 222k/Pdt/2017

Rahmadi Indra Tektona dan Dwi Budi Wasitaresi

Kantor Pelayanan Kekayaan Negara dan Lelang Surabaya sebagai Tergugat III, H. Soelikin selaku Tergugat IV selaku pembeli lelang, dan Kantor Pertanahan Kabupaten Gresik sebagai Tergugat V dengan duduk perkara sebagai berikut :

Hj. Idatul Ifa dan Zainul Arifin telah menikah pada tahun 1993 dan selama pernikahan tersebut keduanya telah memperoleh sebidang tanah pekarangan yang diatas tanah tersebut didirikan bangunan permanen atas nama Zainul Arifin. Kemudian, keduanya memutuskan untuk bercerai di tahun 2006. Namun, sampai gugatan ini diajukan belum dilakukan pembagian harta bersama. Lalu pada tanggal 20 April 2007 tanpa sepengetahuan dan tanpa persetujuan Hj. Idatul Ifa, Zainul Arifin meminjam sejumlah dana kepada Bank Danamon dan menggunakan tanah sekaligus bangunan tersebut sebagai jaminan atas perjanjian kredit.

Bank ketika melaksanakan kegiatan usahanya dalam memberikan pembiayaan (kredit) kepada pihak debitur dibingkai oleh perjanjian kredit sebagai perjanjian pokok dan diiringi dengan perjanjian jaminan kebendaan sebagai perjanjian tambahan (accecoir). Pada hukum perbankan, istilah Jaminan memiliki perbedaan dengan istilah agunan. Pada pengertiannya, agunan merupakan jaminan tambahan, diberikan oleh peminjam (debitur) kepada pihak kreditur dikarenakan diberikannya fasilitas kredit oleh bank atas dasar Prinsip Syariah. Sedangkan jaminan dalam pengertiannya merupakan keyakinan terhadap iktikad serta kesanggupan debitur untuk dalam pengembalian kredit itu dikemudian hari sesuai dengan yang diperjanjikan.

Perjanjian kredit sebagai perjanjian tertulis, wujud kesepakatan antara pihak bank dengan debitur termasuk dalam karena belum diatur secara khusus dalam KUHPerdata. Hal itu dapat dilihat karena perjanjian ini lahir karena adanya asas kebebasan berkontrak sehingga didasarkan atas kesepakatan antara kedua pihak diperkenankan membuat sendiri ketentuan yang dikehendakinya sesuai tujuan hubungan bisnis mereka. Meskipun ketentuan yang dimaksud dirumuskan oleh para pihak sebagai masyarakat biasa karena diwujudkan dengan perjanjian, tetapi perjanjian tersebut tetap disebut sah jika telah memenuhi syarat sah perjanjian sesuai ketentuan pasal 1320 KUHPerdata serta berkekuatan seperti undang - undang terhadap para pihaknya sebagaimana bunyi Pasal 1338 KUHPerdata.

Adapun keabsahan sebuah perjanjian diatur dalam pasal 1320 KUHPerdata terdiri atas syarat subjektif yaitu sepakat antara para pihak serta cakap untuk membuat suatu perikatan, dan syarat objektif yaitu suatu hal tertentu serta suatu sebab yang halal (Santoso \& Lestari, 2017). Apabila syarat subjektif dalam sebuah perjanjian tidak terpenuhi maka dapat dibatalkan. Hal itu berarti perjanjian itu dapat dimintakan pembatalan ke pengadilan oleh pihak yang memiliki kewenangan atas itu, namun selama perjanjian itu tidak dibatalkan oleh hakim akan tetap berlaku bagi para pihak. Adapun pihak yang mempunyai kewenangan untuk memintakan pembatalan terkait perjanjian tersebut merupakan pihak yang tidak cakap atau sepakat tetapi dengan paksaan. Tetapi jika syarat objektif dalam sebuah perjanjian tidak terpenuhi maka disebut batal demi hukum. Hal itu berarti dari awal lahirnya perjanjian itu dianggap tidak pernah ada. Terkait dengan hal tersebut, dapat disimpulkan bahwa dibatalkan dapat terjadi jika sebuah perjanjian tidak memenuhi syarat subyektif sehingga pihak yang memiliki kewenangan dapat mengajukan pembatalan. Sedangkan batal demi hukum dapat terjadi jika tidak memenuhi syarat objektif sehingga dari awal perjanjian tersebut tidak pernah ada.

Perjanjian tambahan (accesoir) lahir sebagai akibat disepakatinya perjanjian pokok yang mendahuluinya (Nurfaizal, 2013). Perjanjian pokok yang dimaksud yaitu berupa perjanjian kredit sedangkan perjanjian tambahannya berupa perjanjian jamina kebendaan. Perjanjian jaminan kebendaan yang berasal dari debitur digunakan sebagai bentuk pengikatan pelunasan terhadap hutang debitur apabila Debitur melakukan wanprestasi atau cidera janji. Pada putusan Mahkamah Agung Nomor 
Khazanah Hukum, Vol. 2 No. 2: 82-91

Kedudukan Jaminan Hak Tanggungan Yang Dibuat Tanpa Persetujuan Mantan Istri Dalam Perbankan : Studi Putusan Mahkamah Agung Nomor 222k/Pdt/2017

Rahmadi Indra Tektona dan Dwi Budi Wasitaresi

222K/PDT/2017 objek jaminan yang diberikan oleh Zainul Arifin kepada Bank Danamon adalah sebidang tanah dengan bangunan diatasnya tercatat atas nama Zainul Arifin sesuai sertipikat Hak Milik No. 481 Kelurahan Sidomukti, Kecamatan Kebomas, Kabupaten Gresik, Surat Ukur No. 52/08.13/2001 tanggal 17 - 10 - 2001 luas $200 \mathrm{~m}^{2}$ dengan batas - batas :
1. Sebelah Utara
: tanah milik H. Ali
2. Sebelah Barat
: tanah milik Mashuri dan Nasibun
3. Sebelah Selatan : tanah milik Romadhon
4. Sebelah Timur : Jl. Dewi Sekardadu

Pengaturan mengenai pemberian jaminan kebendaan oleh debitur kepada pihak bank diatur dalam pasal 8 Undang - Undang Perbankan. Pada praktiknya, pemberian pinjaman berupa pembiayaan oleh bank kepada debitur memicu resiko, sehingga untuk meminimalisir resiko tersebut kreditur meminta jaminan kepada debitur sebagai keyakinan terhadap kemampuan debitur untuk melaksanakan kewajibannya yaitu pengembalian kredit tersebut dikemudian hari sesuai dengan yang diperjanjikan.

Terkait dengan hal tersebut, objek jaminan sebagai agunan oleh Zainul Arifin kepada pihak Bank Danamon merupakan jaminan khusus yakni jaminan kebendaan hak atas tanah berupa jaminan Hak Tanggungan sehingga aturan - aturan mengenai agunan tanah tersebut berpedoman pada Undang Undang Nomor 4 Tahun 1996 tentang Hak Tanggungan atas Tanah Beserta Benda - Benda Yang Berkaitan Dengan Tanah (UUHT). Pada dasarnya, hak tanggungan merupakan hak jaminan yang objeknya berupa tanah beserta benda benda diatasnya yangdigunakan untuk pelunasan hutang oleh debitur dan memberikan hak untuk didahulukan ( pasal 8 Undang - Undang Nomor 4 Tahun 1996). Jaminan Hak Tanggungan pada prakteknya di buat oleh Pejabat Pembuat Akta Tanah dalam dalam bentuk APHT yang di dalamnya berisikan mengenai kebendaan, baik berupa tanah beserta dengan bangunan diatasnya yang dijadikan jaminan terhadap pelunasan atas utang peminjam atau Debitur kepada pemberi pinjaman atau Kreditur. Kewenangan dalam pemberian Hak Tanggungan diatur dalam pasal 8 Undang - Undang Hak Tanggungan bahwa pendaftaran hak tanggungan hanya dapat dilaksanakan oleh pihak yang mempunyai kewenangan terkait dengan objek yang bersangkutan.

Kemudian, perkawinan pada pengertiannya bahwa :

"Perkawinan adalah ikatan lahir batin antara seorang pria dan seorang wanita sebagai suami istri dengan tujuan membentuk keluarga atau rumah tangga yang bahagia dan kekal berdasarkan Ketuhanan Yang Maha Esa (pasal 1 Undang - Undang Nomor 1 Tahun 1974)."

Dengan kata lain, perkawinan merupakan hubungan hukum antara 2 orang manusia yaitu seorang laki - laki dan seorang wanita yang telah mencukupi syarat tertentu, mengikat lahir ataupun batin dengan didasari oleh Ketuhanan Yang Maha Esa dalam waktu yang lama.

Sebuah perkawinan dapat dikatakan sah apabila pekawinan tersebut dilaksakan berdasarkan ketentuan hukum agama masing - masing atau kepercayaan mereka serta dicatat sesuai peraturan yang berlaku di Indonesia. Keabsahan sebuah perkawinan didukung dengan syarat - syarat yang melatarbelakangi untuk sampainya para pihak pada suatu keabsahan tersebut yang mana merujuk pada ketentuan pasal 6 Undang - Undang Nomor 1 Tahun 1974 tentang Perkawinan (selanjutnya disebut Undang - Undang Perkawinan).

Terkait adanya sebuah perkawinan, akibat hukum yang ditimbulkan yaitu lahirnya hak beserta dengan kewajiban bagi seorang suami dan seorang istri yang mana telah diatur dalam pasal 30 sampai pasal 34 Undang - Undang Perkawinan. Selain itu, akibat hukum lain yang timbul setelah terjadinya perkawinan yaitu berkaitan dengan harta perkawinan suami istri. Pada dasarnya, perolehan harta didalam sebuah perkawinan dibagi menjadi dua antara lain harta bersama merupakan seluruh harta 
Khazanah Hukum, Vol. 2 No. 2: 82-91

Kedudukan Jaminan Hak Tanggungan Yang Dibuat Tanpa Persetujuan Mantan Istri Dalam Perbankan : Studi Putusan Mahkamah Agung Nomor 222k/Pdt/2017

Rahmadi Indra Tektona dan Dwi Budi Wasitaresi

benda yang didapatkan semasa perkawinan dan harta bawaan merupakan seluruh harta benda yang didapatkan oleh masing - masing pihak baik hadiah ataupun warisan (pasal 1 Undang - Undang Nomor 1 Tahun 1974). Sehubungan dengan kewenangan bertindak terkait dengan harta bersama, haruslah berdasarkan kesepakatan kedua belah pihak. Sedangkan kewenangan bertindak terkait dengan harta bawaan, beradaadi bawah penguasaannmasing - masing pihak (pasal 1 Undang - Undang Nomor 1 Tahun 1974). Pemberian Hak Tanggungan terdapat di pasal 8 Undang - Undang Hak Tanggungan yang menyatakan bahwasannya dilaksanakan oleh subyek hukum yang mempunyai kewenangan untuk melaksanakan perbuatannhukum terhadap obyek Hak Tanggungan tersebut. Sedangkan kewenangan terkait harta bersama tercantum dalam pasal 36 Undang - Undang Perkawinan yaitu terkait dengan kewenangan bertindak atas harta bersama membutuhkan persetujuan oleh suami dan istri sebab merupakan harta yang didapatkan semasa perkawinan. Oleh sebab itu, kewenangan pemberi Hak Tanggungan terkait harta yang diperoleh semasa perkawinan harus berdasarkan persetujuan keduanya yaitu suami dan istri.

Selain itu, terkait kedudukan suami dan istri dalam melaksanakan perbuatan hukum adalah seimbang (pasal 31 Undang - Undang Nomor 1 Tahun 1974). Sehingga seorang suami atau pun seorang istri diperbolehkan untuk membuat perjanjian kredit dengan bank. Terkait dengan hal itu, apabila suami ataupun istri yang telah terikat dalam sebuah perkawinan dan akan melakukan perbuatan hukum yaitu melakukan perjanjian kredit bersama pihak bank dan menjadikan harta yang diperoleh semasa perkawinan sebagai jaminan Hak Tanggungan dalam perjanjian tambahan (accesoir) maka haruslah dengan persetujuan suami ataupun istrinya. Kecuali sebelum perkawinan diadakan, keduanya telah mengadakan perjanjian perkawinan yang menyatakan pisah harta.

Namun, apabila dikemudian hari terjadi perceraian maka akan berdampak terhadap pembagian harta yang diperoleh semasa perkawinan sebab putusnya sebuah perkawinan yang disebabkan karena perceraian tidak serta merta mengatur tentang hal yang berkaitan dengan pembagian harta yang didapatkan semasa perkawinan. Sehingga apabila sebuah perkawinan telah berakhir disebabkan oleh perceraian namun keduanya sejak awal tidak membuat perjanjian mengani pemisahan harta, maka harus ada putusan terpisah terkait pembagian harta bersama yang mereka miliki.

Berdasarkan penjelasan diatas, dapat dilihat bahwa apabila sebuah perkawinan putus disebabkan perceraian, maka harta yang diperoleh semasa perkawinan tersebut yang telah dibagikan sesuai dengan hukumnya masing - masing maka bagian - bagian yang diterima oleh para pihak telah menjadi harta masing - masing sehingga ketika salah satu pihak ingin mengalihkan ataupun menjaminkan harta tersebut tidak diperlukan persetujuan dari pihak lain karena harta yang dijaminkan tersebut tidak lagi berstatus menjadi harta bersama. Namun, apabila setelah perceraian belum ada putusan ataupun penetapan mengenai pembagian harta bersama maka pihak yang mengalihkan ataupun menjaminkan harta tersebut harus disertai dengan persetujuan dari mantan istri ataupun mantan suami sekalipun harta yang didapatkan semasa perkawinan yang akan dijaminkan atas nama salah satu pihak.

Apabila perkawinan pasangan tersebut telah putus karena perceraian maka juga akan berdampak terhadap kewenangan pemberian hak tanggungan (Herlambang, 2019). Ketika sebuah perkawinan berakhir disebabkan perceraian namun keduanya tidak membuat perjanjian mengenai pemisahan harta, maka harus ada putusan terpisah mengenai pembagian harta bersama yang mereka miliki. Terkait dengan hal itu, apabila sampai saat dilakukannya perbuatan hukum yang dilakukan oleh mantan suami ataupun mantan istri untuk menjaminkan harta bersama belum ada putusan terkait pembagian harta bersama , maka apabila akan menjaminkan harta bersama tersebut harus berdasarkan persetujuan mantan suami ataupun mantan istrinya. 
Khazanah Hukum, Vol. 2 No. 2: 82-91

Kedudukan Jaminan Hak Tanggungan Yang Dibuat Tanpa Persetujuan Mantan Istri Dalam Perbankan : Studi Putusan Mahkamah Agung Nomor 222k/Pdt/2017

Rahmadi Indra Tektona dan Dwi Budi Wasitaresi

Berdasarkan penjelasan diatas dapat diketahui bahwa pada putusan Mahkamah Agung Nomor 222K/PDT/2017 bahwa Hj. Idatul Ifa telah menikah dengan dengan Zainul Arifin pada tahun 1993 di hadapan Pegawai Pencatat Nikah Kantor Urusan Agama Kecamatan Duduk Sampeyan Kabupaten Gresik. Kemudian selama pernikahan tersebut yaitu tahun 2001 telah memperoleh sebidang tanah pekarangan dengan bangunan permanen diatasnya yang tercatat atas nama Zainul Arifin. Kemudian pada tahun 2006 Hj. Idatul Ifa dan Zainul Arifin memutuskan untuk bercerai namun sampai dengan gugatan ini diajukan belum dilakukan pembagian mengenai harta yang diperoleh semasa perkawinan, sehingga sesuai ketentuan pasal 35 Undang - Undang Perkawinan secara hukum tanah dan bangunan tersebut berstatus sebagai harta bersama. Kemudian, belum adanya putusan dari pengadilan mengenai pembagian harta bersama mengakibatkan apabila Zainul Arifin menjaminkan ataupun mengalihkan sebidang tanah pekarangan dengan bangunan permanen diatasnya tersebut haruslah dengan persetujuan $\mathrm{Hj}$. Idatul Ifa sesuai ketentuan pasal 36 ayat (1) Undang - Undang Perkawinan.

Berkaitan dengan kewenangan bertindak untuk menjaminkan atau mengagunkan tanah dan bangunan dengan Sertipikat Hak Milik Nomor 481 kepada Bank Danamon selaku Kreditur, dalam hal ini Zainul Arifin tidak memiliki kewenangan berdasarkan:

\section{Kewenangan bertindak untuk dan atas namanya sendiri, yang berkaitan dengan kecakapannya untuk bertindak dalam hukum;}

Zainul Arifin tidak memiliki kewenangan bertindak untuk dan atas namanya sendiri karena menurut kasus posisi pada putusan pengadilan tersebut, tidak pernah ada Perjanjian Kawin antara Zainul Arifin dengan Mantan Isteri yaitu Hj. Idatul Ifa sehingga menurut hukum harta tanah serta bangunan diatasnya tersebut merupakan harta bersama antara Zainul Arifin dengan $\mathrm{Hj}$. Idatul Ifa. Apabila Zainul Arifin ingin menjaminkan atau mengagunkan harta tersebut maka haruslah atau memerlukan persetujuan dari $\mathrm{Hj}$. Idatul Ifa karena dilihat dari perolehan hartanya yaitu setelah perkawinan.

\section{Kewenangan untuk bertindak selaku kuasa pihak lain, yang dalam hal ini tunduk pada ketentuan yang diatur dalam Bab XVI BW;}

Zainul Arifin tidak memiliki kewenangan untuk bertindak sebagai kuasa pihak lain dalam hal ini adalah $\mathrm{Hj}$. Idatul Ifa, karena Hj. Idatul Ifa sama sekali tidak pernah memberikan kuasa kepada Zainul Arifin untuk menjaminkan tanah serta bangunan Sertipikat Hak Milik Nomor 481 kepada Zainul Arifin.

\section{Kewenangan untuk bertindak dalam kapasitasnya sebagai wali atau wakil dari pihak lain (Widjaja \& Muljadi, 2003).}

Zainul Arifin dia tidak memiliki kewenangan untuk bertindak sebagai wali.

Terkait dengan hal diatas, dalam menjadikan tanah tersebut sebagai jaminan Hak Tanggungan maka pemberi jaminan Hak Tanggungan tersebut haruslah subyek hukum yang memiliki kewenangan terhadap objek Hak Tanggungan tersebut (Pasal 8Undang - Undang Hak Tanggungan ), dalam hal ini yaitu Zainul Arifin dan Hj. Idatul Ifa.

Berdasarkan penjelasan diatas dapat diketahui bahwa diberikannya jaminan kebendaan yang berasal dari debitur sebagai jaminan kredit kepada pihak Bank sebagai pihak kreditur diatur dalam pasal 8 Undang - Undang Perbankan. Pemberian benda jaminan yang berasal dari harta bersama yang didapatkan semasa perkawinan pasangan suami dan istri yang sudah berakhir disebabkan perceraian juga tidak diatur dalam Peraturan bank Indonesia ataupun Peraturan Otoritas Jasa Keuangan. Harta 
Khazanah Hukum, Vol. 2 No. 2: 82-91

Kedudukan Jaminan Hak Tanggungan Yang Dibuat Tanpa Persetujuan Mantan Istri Dalam Perbankan : Studi Putusan Mahkamah Agung Nomor 222k/Pdt/2017

Rahmadi Indra Tektona dan Dwi Budi Wasitaresi

bersama suami istri diatur oleh peraturan Undang - Undang Nomor 1 Tahun 1974 tentang Perkawinan dan dihubungkan dengan Undang - Undang Nomor 4 Tahun 1996 tentang Hak Tanggungan.

\section{SIMPULAN}

Kepastian hukum dalam pemberian benda jaminan yang berasal dari harta Bersama yang didapat semasa perkawinan pasangan suami istri yang sudah berakhir disebabkan perceraian tidak diatur dalam Hukum Perbankan, baik dalam Undang - Undang Nomor 7 Tahun 1992 tentang Perbankan, Undang Undang Nomor 10 Tahun 1998 tentang Perubahan atas Undang - Undang Nomor 7 Tahun 1992 tentang Perbankan, Peraturan Bank Indonesia, maupun Peraturan Otoritas Jasa Keuangan, sehingga tunduk kepada Undang - Undang Nomor 1 Tahun 1974 Tentang Perkawinan dan Undang - Undang Nomor 4 Tahun 1996 Tentang Hak tanggungan, dimana masih dirasa kurang kuat, melihat akhir - akhir ini sering terjadi kasus serupa dan merugikan salah satu pihak. Hal tersebut mengakibatkan kepastian hukum tidak dapat berjalan dengan maksimal.

Kepada pemerintah diharapkan untuk menjamin kepastian seluruh pihak yaitu membuat peraturan mengenai unifikasi perkreditan. Hal ini dilakukan sebab mengenai perkreditan dalam dunia perbankan berkaitan dengan peraturan perundang - undangan lainnya seperti Undang - Undang Nomor 4 Tahun 1996 tentang Hak Tanggungan ataupun peraturan perundang - undangan yang lain. Selama ini, peraturan perkreditan yang berlaku merujuk pada berbagai ketentuan seperti buku ketiga KUHPerdata, Undang - Undang Nomor 7 Tahun 1992 tentang Perbankan sebagaimana telah diubah dengan Undang Undang Nomor 10 Tahun 1998 tentang Perubahan atas Undang - Undang Nomor 7 Tahun 1992 tentang Perbankan serta peraturan perundang - undangan lain sehingga terjadi pengaplikasian yang tidak tetap serta kurang memberikan kepastian hukum bagi para pihak

\section{DAFTAR PUSTAKA}

Budiawan, A. (2018). MODERNISASI HUKUM KELUARGA DI INDONESIA: Studi Terhadap Diskursus dan Legislasi Perjanjian Perkawinan Islam Indonesia. Madania:Jurnal Ilmu-Ilmu Keislaman, $7(2), 211-240$.

Herlambang, A. (2019). Implementasi dan Efektivitas Mediasi Perceraian oleh Hakim Mediator di Pengadilan Agama Sleman Tahun 2017 Perspektif Perma No. 1 Tahun 2016.

IBRAHIM, M. A., Turatmiyah, S., \& Handayani, S. (2019). ANALISIS HAK TANGGUNGAN YANG OBJEKNYA DALAM PROSES SENGKETA (STUDI PUTUSAN MAHKAMAH AGUNG NOMOR: 2301 $K / P d t / 2007)$. Sriwijaya University.

Isnaeni, M. (2016). Pengantar Hukum Jaminan Kebendaan. Surabaya: Revka Petra Media.

Khoidin, M. (2017). Hukum Jaminan (Hak-Hak Jaminan, Hak Tanggungan dan Eksekusi Hak Tanggungan). Surabaya: Laksbang Yustisia.

Mertokusumo, S. (2010). Mengenal Hukum Suatu Pengantar (Edisi Revisi). Cahaya Atma Pustaka, Yogyakarta.

Munif, N. A. (2017). Analisis Akad Ijarah Muntahiyabittamlik Dalam Perspektif Hukum Islam Dan Hukum Positif Di Indonesia. An-Nisbah: Jurnal Ekonomi Syariah, 3(2), 255-276.

Nurfaizal, N. (2013). Prinsip-Prinsip Muamalah Dan Inplementasinya Dalam Hukum Perbankan Indonesia. Hukum Islam, 13(2), 170-176.

Pius, K. P. (2013). Diktat Perkuliahan Mata Kuliah Hukum Perbankan: Hukum Perjanjian Kredit Bank. Jember: Universitas Jember.

PURWANDARI, H. (2018). KEDUDUKAN DAN PERLINDUNGAN HUKUM TERHADAP KREDITUR APABILA HAK TANGGUNGAN DINYATAKAN BATAL DEMI HUKUM DI PENGADILAN NEGERI WONOSARI. Universitas Islam Indonesia. 
Khazanah Hukum, Vol. 2 No. 2: 82-91

Kedudukan Jaminan Hak Tanggungan Yang Dibuat Tanpa Persetujuan Mantan Istri Dalam Perbankan : Studi Putusan Mahkamah Agung Nomor 222k/Pdt/2017

Rahmadi Indra Tektona dan Dwi Budi Wasitaresi

Santoso, L., \& Lestari, T. W. S. (2017). Konparasi Syarat Keabsahan "Sebab Yang Halal" Dalam Perjanjian Konvensional Dan Perjanjian Syariah. Al-Istinbath: Jurnal Hukum Islam, 2(1), 116.

Sugiyono. (2013). Memahami Penelitian Kualitatif. Bandung: CV. Alfabeta.

Suyandi, D. (2019). THE EFFECT OF MUDHARABAH FINANCING PRODUCTIVITY AND INCREASING THE MEMBER'S CAPITAL BUSINESS ON THE INCOME OF MARDHOTILAH BMT MEMBERS. International Journal of Islamic Khazanah, 9(1), 23-28.

Taka, A. J. (2015). HARTA BERSAMA YANG DIPERJUALBELIKAN DAN DIJAMINKAN TANPA PERSETUJUAN MANTAN ISTERI. CALYPTRA, 4(2), 1-19.

Widjaja, G., \& Muljadi, K. (2003). Penanggungan utang dan perikatan tanggung menanggung. Divisi Buku Perguruan Tinggi, RajaGrafindo Persada.

Zaman, M. D. B., \& Darus, M. (1991). Perjanjian kredit bank. PT Citra Aditya Bakti, Bandung. 